\title{
四uke $\mathfrak{I} \mathfrak{a} \mathfrak{w}$ Journal
}

\begin{tabular}{lll}
\hline VOLUME I959 SUMMER NUMBER 3 \\
\hline
\end{tabular}

\section{MR. JUSTICE STEWART ON THE COURT OF APPEALS}

\author{
J. Francis Paschal *
}

I

THE NAMING of a new justice to the Supreme Court quite properly interests the country at large as well as the profession. What, we always want to know, has he said or done in the past? What, the reporters always ask, is his "judicial philosophy"? In the case of $\mathrm{Mr}$. Justice Stewart, we perhaps ought to eschew the latter inquiry because he himself has told us: "I really don't know what it is." I It may be useful, however, even though we can answer the question no more positively than the new appointee, to look briefly at some aspects of his career on the Court of Appeals for the Sixth Circuit, on which he served for over four years immediately prior to his appointment. But first, the scanty vital statistics should be noted.

Stewart's path is the well-worn one leading from Cincinnati to Yale College and Yale Law School, where he was graduated in 1941. As an undergraduate, he served as chairman of the Yale Daily Neres, and in law school, was the comment editor of the Yale Law Journal. After seeing duty with the Navy during the war, he finally landed back in Cincinnati for a period of practice before his initial judicial appointment in $1954 .^{2}$

Of his intellectual comings and goings in this period, one knows little. As an undergraduate, Stewart announced for the Yale Daily Neres: "Because we believe wholeheartedly in the philosophy of the

* B.A. 1935, LL.B. 1938, Wake Forest College; M.A. 1942, Ph.D. 1947, Princeton University. Professor of Law, Duke University. Author, Mr. Justice SuTherLand (1951). Contributor to legal publications.

${ }^{2}$ N.Y. Times, Oct. 8, 1958, p. I, col. I.

${ }^{2}$ Stewart was appointed to the Court of Appeals in June 1954. He was associated in Cincinnati with the firm of Dinsmore, Shohl, Sawyer \& Dinsmore, becoming a partner in 1951 . This paragraph in the text and the succeeding one are drawn from the N.Y. Times, Oct. 8, 1958, and 4 Yale Law Report No. 3, pp. 9-I I (Winter 19.58). 
New Deal, we shall, in general, support the President." Possibly, he now regards this as a youthful indiscretion. At any rate, back in Cincinnati, he was a Republican and was twice elected to the city council. $\mathrm{He}$ is said to have been suggested to the President as a Supreme Court nominee by Senator Bricker ${ }^{3}$ and to enjoy the approval of representatives of the American Bar Association, along with the enthusiastic support of his professors at Yale. ${ }^{4}$

\section{II}

When Stewart was appointed to the Court of Appeals in 1954, he brushed aside a suggestion that he might be somewhat handicapped in his work on the bench by his lack of judicial experience with the comment that "being fair-minded is something that's either there or not." While this remark was hardly intended to do service as a philosophy of law, it does perhaps provide a significant clue to the present Justice's scheme of values. For while he often revealed a solicitude for other values, this concern that the end product of the law shall bear the stamp of fair-mindedness was never long out of sight. It will not do to dismiss this concern as unimportant merely because it is subscribed to by the entire judicial fraternity, or because Stewart might sometimes have seemed quixotic in his concept of fairness, or because he was sometimes unequal to the task of synthesizing his notions of fairness with defensible legal doctrine. ${ }^{8}$ For, on other occasions, Stewart did

\footnotetext{
${ }^{3}$ N.Y. Times, Oct. 8, 1958, p. 26, col. I. The Times added: "However, it is known that the Justice Department has had its eye on Judge Stewart for some time and had recoummended him for the job independently of any recommendations that might have been made by the Senator."

"Dean Rostow said that Stewart "will be an excellent justice . . . one of the strong members" of the Court. Professor Gulliver remarked that Stewart was "one of the most intelligent, dynamic and personally attractive students who have attended the Yale Law School in the past thirty years."

${ }^{5}$ N.Y. Times, Oct. 8, 1958, p. 24, col. 2. The Yale Law Report renders what is possibly the same remark as: "Fairness is really what justice is." 4 Yale Law Report, op. cit. supra note 2, at Io.

${ }^{8}$ See Shepard v. United States, 257 F.2d 293 (6th Cir. 1958). Here, Stewart denied a plea that a sentence be revised because of a flagrant disparity. The prisoner argued that he was no more guilty than others who had been his confederates in a counterfeiting ring and that whereas the confederates were sentenced in another court to terms of only one to six and one-half years, he had received a sentence of 15 years. Plainly troubled by the situation, Stewart wrote:

"Every year numerous appeals come before this court which accentuate a seriously urgent problem-the disparity of sentences in federal criminal cases. The present appeal is illustrative. Justice is measured in many ways, but to a convicted criminal its surest measure lies in the fairness of the sentence he receives. Whether a sentence is fair cannot, of course, be gauged simply by comparing it with the punishment imposed
} 
accomplish this synthesis. Indeed, had his views prevailed, much of the iniquity of the retroactive provisions of the Immigration and Nationality Act of $1952^{7}$ would now be behind us.

Stewart had his say on this problem in a case ${ }^{8}$ involving the Government's effort to deport one Carson who had entered this country as a stowaway in 1919. Later, in 1936, Carson was convicted of two criminal offenses, and deportation proceedings were instituted against him. But these proceedings were abandoned when Carson received a "conditional pardon" in 1945. This pardon rendered Carson immune from deportation under the law then in effect, and he had long before achieved a like immunity in respect to his illegal entry in I919. However, after the passage of the 1952 Act, with its retroactive provisions, ${ }^{9}$ the Government again tried to deport Carson because of the earlier convictions and because of his illegal entry. Carson sought refuge in the savings clause ${ }^{10}$ of the Act, which declared that "unless otherwise specifically provided," nothing in the Act should "be construed to affect the validity of . . . any status, condition, [or] right in process of acquisition ... existing at the time this Act shall take effect. ..." The Government, in reply, argued that there had been specific provision "otherwise"; that the section making illegal entry and criminal conviction grounds for deportation had also included a provision that the section should apply "notwithstanding" that its effect would be retroactive."1

Perhaps this "notwithstanding" language together with that em-

upon others for similar offenses. But that test, though imperfect, is hardly irrelevant. It is an anomaly that a judicial system which has developed so scrupulous a concern for the protection of a criminal defendant throughout every other stage of the proceedings against him should have so neglected this most important dimension of fundamental justice." Shepard v. United States, supra at 294. See generally the symposium, Sentencing, 23 LAW \& Contemp. ProB. 399 (1958).

${ }^{7}$ Immigration and Nationality Act of 1952 , 66 Stat. 163,8 U.S.C. $\$ \$ 1101-503$, as amended, 8 U.S.C. $\$ \S \times 15 \mathrm{I}-48$ I (Supp. V, 1958).

${ }^{8}$ United States ex rel. Carson v. Kershner, 228 F.2d 142 (6th Cir. 1955) reqd sub nom. Lehmann v. United States ex rel. Carson, 353 U.S. $68_{5}$ (1957).

- Immigration and Nationality Act of 1952, 66 Stat. 204, 8 U.S.C. $\$ 1251$, as amended, 8 U.S.C. \$ 125 I (Supp. V, 1958).

${ }^{10}$ Immigration and Nationality Act of 1952, 66 Stat. 280, 8 U.S.C. $\$$ I ror.

11 Immigration and Nationality Act of 1952,66 Stat. 208, 8 U.S.C. $\$ 1251$ (d). The language referred to was: "(d) Except as otherwise specifically provided in this section, the provisions of this section shall be applicable to all aliens belonging to any of the classes enumerated in subsection (a) of this section notwithstanding ( 1 ) that any such alien entered the United States prior to June 27, 1952, [the date of enactment of this Act] or (2) that the facts, by reason of which any such alien belongs to any of the classes enumerated in subsection (a) of this section, occurred prior to June 27, 1952 [the date of enactment of this Act]." (Emphasis added.) 
phasized in the footnote is clearly a specific provision "otherwise." The Supreme Court, all nine, later thought the matter so obvious that it contented itself with merely quoting the disputed sections of the Act. ${ }^{12}$ But Stewart was unwilling to yield the point without a fight. Congress had not been as specific as it might have been; it could have expressly stated that the savings clause did not affect proceedings under the section in question. Moreover, a unanimous Supreme Court had said in United States $v$. Menasche ${ }^{13}$ that the savings clause was to receive a most generous interpretation, that the clause manifested "a well-established Congressional policy not to strip aliens of advantages gained under prior laws." Nor was Stewart unmindful of his obligation to give section I25Id (containing the "notwithstanding" language) some effect. It could be used, he pointed out, to ensnare the alien who had not achieved a status of immunity from deportation although the acts on which a proceeding was based had occurred prior to the passage of the I952 law and at the time were insufficient to support an action against the alien. Unless some such interpretation was adopted, he reasoned, the savings clause would be "all but meaningless," for only where there had been a change in the law was such a clause "of any moment at all." 14

Stewart's opinion in Carson's case, for all its audacity, does not show him to be unmindful of the complexities of fairness. But even more striking in this connection is the one segregation case that he heard before coming to the Supreme Court. ${ }^{15}$ In this case, Stewart had an experience which makes him unique among Supreme Court justices, in that he alone has faced the aftermath of the Brown ${ }^{10}$ decision from the standpoint of a judge who must direct in detail the framing of a decree to meet a particular situation. The case came from the small Ohio town of Hillsboro where, soon after the first Brown opinion, ${ }^{17}$ the school board set up a school district plan patently devised to continue segregation until some new buildings would be available two or three years later.

\footnotetext{
${ }^{12}$ Lehmann v. United States ex rel. Carson, 353 U.S. 685 (1957). Justices Black and Douglas, although joining in the Court's interpretation of the Act, dissented on constitutional grounds.

${ }^{13} 348$ U.S. 528,535 (1955) where a status in respect to naturalization was held to be preserved. See also, Shomberg v. United States, 348 U.S. 540 (1955).

1" United States ex rel. Carson v. Kershner, 228 F.2d 142, 147 (6th Cir. 1955).

${ }^{16}$ Clemons v. Board of Education, 228 F.2d 853 (6th Cir.), cert. denied, 350 U.S. 1006 (1956).

${ }^{16}$ Brown v. Board of Education, 349 U.S. 294 (1955).

${ }^{12}$ Brown v. Board of Education, 347 U.S. 483 (1954).
} 
In a class action, seven Negroes sought for themselves and all others similarly situated an immediate end to the enforcement of the plan. The district judge, impressed by the board's plea that the white schools were already overcrowded and the board's assurances that the situation would be alleviated on the completion of the new buildings, refused injunctive relief. The plaintiffs appealed.

Judgment was rendered by the court of appeals early in January 1956. One of the three judges was willing to allow the district court decision to stand, on the ground that the grant of the equitable relief sought was a matter of discretion. But Stewart and his associate, Judge Allen, joined in declaring that the plaintiffs' claim was a "matter of right." For Judge Allen, this ended the matter. The plaintiffs were entitled immediately to the relief they sought. But for Stewart, the situation was not so simple. He recognized that the "deliberate speed" formula gave the trial judge no excuse for an outright refusal of injunctive relief. He intimated that this would have been true even had the case come, not from Ohio, where segregation had not been authorized by law for over seventy years, but from some area where what was involved was "the uprooting of a system of education built upon decades of state custom and state law."18 Yet, he could not agree that the segregation plan was to be outlawed forthwith in its entirety. It was, he remarked, already mid-year. Necessarily, there were others-teachers and students-who would be affected by the immediate end of all segregations and "a wholesale shifting of . . . Negro and white children [then] in school might ... serve to cause dislocation and hardship out of proportion to the purpose to be served."19 The solution, therefore, was to delay relief until the following September for those Negro children then in school. Those not in school, on the other hand, were entitled to immediate relief, since the hardship feared by Stewart-the adjustment by teachers and students to newcomers in the midst of a school year-would follow inevitably regardless of the "color" of the school they chose to attend.

Obviously, in the segregation case just discussed, we can see a mind sensitive to the complexities of fairness. But it should be clear already that this sensitivity did not produce in Stewart a paralyzing indecisiveness resulting eventually in abandoning the pursuit of fairness because, perchance, the way is hard. Indeed, in one case, considered at one

\footnotetext{
${ }^{28}$ Clemons v. Board of Education, 228 F.2d 853,859 (6th Cir. 1956) (concurring opinion).

${ }^{10}$ Ibid.
} 
time or another by over twenty judges, Stewart alone concluded that there had been unfairness and was willing to do something about it. The problem involved was the right to counsel. In I942, a Negro in Michigan named Henderson was sentenced to life imprisonment, the maximum penalty, on his plea of guilty to a charge of rape. Years later, he sought a new trial in the Michigan courts and, on the eventual denial of his motion, ${ }^{20}$ sought relief in the federal district court through habeas corpus, on the ground that he neither had nor was offered counsel and that his plea of guilty was induced by fear of mob action. ${ }^{21}$

Since the Michigan courts had found, on the new trial motion, on substantial evidence, that there was no intimidation of the accused, Stewart joined his colleagues in denying relief on that ground, although he seemingly was doubtful on the point. ${ }^{22}$ But he was unwilling to accept the majority conclusion that lack of representation in the circumstances of this case was to be disregarded.

Henderson had surrendered himself late one afternoon. After questioning by the police, there followed in rapid-fire order, that same evening, waiver of examination when arraigned before a justice of the peace brought to the jail; the filing of an information by the prosecuting attorney; and finally, at ro:20 P.M., the convening of the Circuit Court, with only the judge, the prosecutor, three policemen, and the court reporter present in addition to Henderson. After some interrogation by the judge and a plea of guilty, Henderson received a life sentence.

Sixteen years later, the judges for the sixth circuit could not agree on just what the Michigan trial judge had established at his night session. A majority was certain that there was no constitutional flaw in the proceedings, no invalidating "ingredient of unfairness."23 Henderson, in its judgment, must be held to have understood the nature of the charges against him and the consequences of a guilty plea. He was, at the time of sentence, twenty-five years old and had had previous brushes with

\footnotetext{
${ }^{20}$ People v. Henderson, 343 Mich. 465, 72 N.W.2d 777 (1955), cert. denied, 351 U.S. 967 (1956).

${ }^{21}$ Henderson v. Bannan, 256 F.2d 363 (6th Cir. 1958), cert. denied, 358 U.S. 890 (1958).

${ }^{29}$ Henderson claimed that a mob had actually formed and that he himself saw it from the courthouse. It was demonstrable that Henderson had not seen a mob, and there was little evidence that there was one. Henderson v. Bannan, supra note $2 \mathrm{I}$, at 376. But there was a possibility that Henderson was indeed in fear of a mob. As Stewart put it: "What was the reason for these speedy proceedings in the dead of night? The motivation seems clearly to have been fear of possible mob violence." Henderson v. Bannan, supra at 385 (dissenting opinion).

${ }^{33}$ Foster v. People, 332 U.S. 134, I 37 (1947).
} 
the law, in one of which he had been defended by a court-appointed attorney. In the present habeas corpus proceeding, the trial judge had found from his demeanor that he was "an intelligent and aggressive personality, keenly alert to his legal rights."24 Moreover, although Henderson now claimed that he had sought the aid of counsel, he was met by the contrary finding on this point in the Michigan court and in the district court.

For Stewart-and as has been indicated, he alone of all the judges who considered this case took this view-"the mere recital of the headlong succession of events which culminated in the imposition of Michigan's extreme penalty is enough to invoke grave doubt that the fundamentals of due process of law could have been observed without counsel to assist the defendant. ${ }^{225} \mathrm{He}$ charged the majority with the attitude that Henderson's guilt was so obvious, appointment of counsel would have made no difference. ${ }^{26}$ But what legally constitutes rape in Michigan, he argued, is hardly a simple matter. There must be "resistance to the utmost," and there are other subtle distinctions as well. ${ }^{27}$ As for Henderson's understanding of the consequences of his plea, the record that seemed sufficient to the majority suggested to Stewart that information of these consequences had been imparted in only the "most tentative and hypothetical way."28 And, unlike his colleages, Stewart was not willing to accept the finding of the trial judge that Henderson had not sought counsel. There was evidence that before the waiver of preliminary examination at the arraignment, Henderson, in response to a police officer's question as to whether he wanted counsel, had replied that he did not. But Henderson's testimony of what went on while he was before the justice of the peace was: "I asked him why they wouldn't let me call my brother and why wasn't it possible to have an attorney. . . "29

\footnotetext{
${ }^{24}$ Henderson v. Bannan, 256 F.2d 363, 380 (6th Cir. 1958).

${ }^{25} 1 d$. at 387 (dissenting opinion). ${ }^{30} 1 d$. at 388 (dissenting opinion).

${ }^{27} I d$. at 387 (dissenting opinion) where Stewart collects the Michigan cases. Stewart relies heavily on United States ex rel. Savini v. Jackson, 250 F.2d 349 (2d Cir. 1957) where a Michigan rape plea of guilty without aid of counsel was nullified.

${ }^{28} I d$. at $3^{88}$ (dissenting opinion). Stewart supplied the following from the record: "Q. You know it carried a life sentence, do you? A. I dilin't know that, no sir, $I$ didn't know that, sir.

Q. Do you have any idea what kind of sentence it carries? A. Somewhat sir, I have heard of cases, sir.

Q. What? A. I have heard of several cases, sir.

Q. The fact it might carry a life sentence, that make any difference in your plea of guilty? A. I wouldn't change my plea because I know I am guilty; no use trying to run around-trying to fight it."

${ }^{20} I d$. at 390 (dissenting opinion).
} 
In spite of the evidence of earlier abandonment to the police of of the idea of counsel, Stewart argued that Henderson's testimony must be regarded as uncontradicted and, therefore, accepted. The accused could not be said to have waived his rights: ${ }^{30}$

The uncorroborated statement of the police officer was insufficient in my opinion to support a conclusion that Henderson was either apprised of or intelligently waived a Constitutional right which the circumstances of this case make such a vital one. "Where the right to counsel is of such critical importance as to be an element of Due Process under the Fourteenth Amendment, a finding of waiver is not lightly to be made."

When he came to consider the problems raised by legislation directed at subversives, Stewart continued to pursue his ideal of a balanced fairness incorporated in defensible doctrine. While keenly aware, as we have seen, that the Immigration Act "bristles with severities," he sought no escape from these severities by a strained assessment of the facts in a particular case. Thus, in a deportation proceeding based on former membership in the Communist Party, he did not hesitate to declare that one who had attended meetings of the Party, who had served the Party as "Educational Director," and who had been a group leader of a Communist club, was in a "meaningful association" with the Party. $^{31}$ On the other hand, Stewart would tolerate no shortcuts, procedural or otherwise, merely because the subversive issue was present. NLRB v. Lannom Mfg. Co. ${ }^{32}$ is illustrative. There, the court of appeals had to decide what to do with an NLRB enforcement petition against an employer when an officer of the complaining union, although previously convicted of perjury in respect to the required non-Communist affidavit, had since his conviction filed a new affidavit. If we pass over the question of whether the Board can deny a compliance status to a union whose officer falsely swears that he is not a Communist and

\footnotetext{
${ }^{30} I d$. , quoting from Moore v. Michigan, 355 U.S. 155, 161 (1957).

${ }^{21}$ Wellman v. Butterfield, 253 F.2d 932 (6th Cir. 1958). See also Williams v. Mulcahey, 253 F.2d 709 (6th Cir. 1957) and cf. Rowoldt v. Perfetto, 355 U.S. 115 (r957). On membership, so far as the Taft-Hartley affidavit is concerned, Stewart has espoused the view set forth by Mr. Justice Burton in Jencks v. United States, 353 U.S. 657, 679-80 (1957). Lohman v. United States, 251 F.2d 951 (6th Cir. 1958) where Stewart found the lower court's instructions insufficient in that it was not emphasized to the jury that the accused must be found to have "desired" Party membership and that the Party considered the accused to be a member.

${ }^{32} 226$ F.2d 194 (6th Cir. 1955), rev'd stib nom. Amalgamated Meat Cutters Workmen v. NLRB, 352 U.S. 153 (1956).
} 
the further question of whether a court can do so, there is still the problem of whether the falsity of the new affidavit can properly be inferred from the adjudicated falsity of the prior affidavit. A majority thought that it could, applying a presumption that the officer's former status as a Communist continued. Stewart, after noting that sinners could always repent, and, indeed, that it was the goal of the Act that they should, remarked: $:^{33}$

A jury has found that in 1950 [the union officer] was both a Communist and a liar, to put it bluntly. Yet to indulge in the presumption that he was therefore guilty of committing a criminal offense a year later in filing the $195 \mathrm{I}$ affidavit is further than I can go on the record before us.

In respect to the Smith Act, ${ }^{34}$ Stewart has, again, had an experience unique for a Supreme Court justice. He has had to interpret and apply the Yates case ${ }^{36}$ teaching on the question of proof necessary to convict in a "conspiracy to advocate" prosecution. ${ }^{36}$ Specifically, the question before him was: What relevance does evidence of Communist Party doctrine have when the defendants are admittedly members of the Party? The courts of appeals have differed on the answer. ${ }^{37}$

The problem came before Stewart in a case he heard on remand from the Supreme Court following the Yates decision. But he had also participated in the initial decision in his court. ${ }^{38}$ He then had joined his colleagues in denying that the "organizing" count was barred by the statute of limitations. He had further joined in saying that the evidence was sufficient to support a conviction on the "advocacy" count.

On remand, the "organizing" count was, of course, untenable, and since the evidence and instructions relating to it were hopelessly intermingled with the evidence and instructions relating to the "advocacy" count, the defendants undoubtedly were entitled to a new trial. But were they entitled to an acquittal? The court unanimously answered

${ }^{33} I d$. (dissenting opinion) at 200. The Supreme Court disposed of the case on the ground that the Board had no power to deny a compliance status, but Mr. Justice Frankfurter thought Stewart's approach an additional ground for reversal. Id. at i53 (concurring opinion).

34 18 U.S.C. $\$ \S 371,2385$ (1952).

${ }^{35}$ Yates v. United States, 354 U.S. 298 (1957).

${ }^{30}$ Wellman v. United States, 253 F.2d 601 (6th Cir. 1958).

${ }^{32}$ United States v. Silverman, 248 F.2d 67 I (2d Cir. 1957); Wellman v. United States, supra note 36 . (1957).

${ }^{30}$ Wellman v. United States, 227 F.2d 757 (6th Cir. 1955), rev'd 354 U.S. 931 
in the negative, but for different reasons. A majority relied, in part, as the court had when the case was first before it, on the evidence in the record relating to the teachings of the Communist Party. These teachings, they asserted, could be used to support a jury finding that the speech of the defendants was not mere theoretical disquisition, but was an incitement to action.

This cannot categorically be pronounced erroneous. It all depends on whether or not there was evidence that the Communist Party advocated not only the violent overthrow of the Government, but advocated action to accomplish that end. On this point, the majority asserted that their "conclusions with respect to the objectives of the Communist Party, are not affected by Yates." 30 Stewart rejoined: "I do not agree. ..." $\mathrm{me}$ Has right, of course, if the evidence before him was no more compelling than that in Yates: For the Supreme Court had found the evidence in the Yates case insufficient to support a conclusion that the Communist Party advocates action. ${ }^{41}$ Unfortunately, however, Stewart did not base his disagreement on the inadequacy of the evidence before him in respect to Communist Party teaching. Instead, he spoke of Yates as holding that the illegal conspiracy could not be proved by showing the defendants' "identification with the Party and inferentially with its tenets." ${ }^{42}$ But the Yates decision does not, as Stewart seems to imply, bar the drawing of inferences from the teachings of the Party. The important thing in this connection is that if the evidence is insufficient to warrant a finding that the teachings of the Party included advocacy of action, then an individual's active identification with the Party cannot furnish a basis for inferring that he advocated action. ${ }^{43}$

Besides disagreeing with the majority on the significance of Communist Party teaching, Stewart differed from them in placing reliance on certain statements attributed to the defendants, such as an assertion that

${ }^{30}$ Wellman v. United States, 253 F.2d 601, 607 (6th Cir. 1958).

${ }^{\circ} I d$. (concurring opinion) at 609 .

"Yates v. United States, 354 U.S. 298 (1957).

"Wellman v. United States, 253 F.2d 60x, 609 (6th Cir. 1958) (concurring opinion).

${ }^{18}$ Yates v. United States, 354 U.S. 298, 329 (1957). The Court said: "[B]oth the record and the Government's brief in this Court make it clear that the Government's thesis was that the Communist Party, or at least the Communist Party of California constituted the conspiratorial group, and that membership in the conspiracy could therefore be proved by showing that the individual petitioners were actively identified with the Party's affairs and thus inferentially to its tenets. This might kave been well enought towards making out the Government's case if advocacy of the abstract doctrine of forcible overthrow satisfied the Smith ACt. . ." (Emphasis added.) 
Negroes in the South constituted "a nation within a nation and were entitled to their own government." ${ }^{34}$ It was enough for him that the possibility of guilt had not been dispelled to the point where a new trial was improper: ${ }^{45}$

Like the Yates defendants, the present appellants were associated, although more closely, with the founding and operation of a school where Marxist theory and technique comprised the entire curriculum. The school was closed to the public. To be sure, the statements in the present record attributed to the defendants in their teaching were equivocal and, taken singly susceptible of a Constitutionally protected interpretation. However, viewed as a consistent pattern and considered along with the appellants, alleged preparation to go "underground," and their efforts to concentrate membership in the basic industries, the evidence is sufficient to justify this court in affording the government an opportunity to retry the appellants. ...

Turning now to a less spectacular area of the criminal law, one can find that on the court of appeals, Stewart was much concerned with the problem of the allowable "unit of prosecution." His very first opinion dealt with this problem. ${ }^{48} \mathrm{He}$ then had to decide whether cumulative punishment was permitted under the Mann Act, ${ }^{47}$ when two women were transported across a state line for immoral purposes on a single trip. Later, Stewart was to speak for his circuit when the transportation of frearms was involved, ${ }^{48}$ and still later, he wrote the opinion in a case dealing with separate convictions for the sale and possession of narcotics. ${ }^{49}$ While the problems in these cases are, of course, not identical, they are sufficiently related to portray an evolution of some interest.

In the Mann Act case, Stewart had an open choice, there being a sharp division in the specific precedents. Stewart chose the two-offense

\footnotetext{
"Wellman v. United States, 253 F.2d 601, 609 (6th Cir. 1958) (concurring opinion),

"s Ibid.

${ }^{48}$ Bell v. United States, 213 F.2d 629 (6th Cir. 1954), rev'd 349 U.S. 8I (1955).

${ }^{47}$ I8 U.S.C. \& 2421 (1952).

${ }^{28}$ Rayborn v. United States, 234 F.2d 368 (6th Cir. 1955).

${ }^{10}$ Yancy v. United States, $252 \mathrm{F.2d} 175$ (6th Cir. 1958). Stewart also sat where the problem was raised in the context of using the mails to defraud, Schumpart v. United States, 245 F.2d 233 (6th Cir. 1957), and where one was charged with transporting and concealing the same stolen automobile, Crawford v. United States, 214 F.2d 313 (6th Cir. 1954).
} 
view. He was not content to rely on a semantic resolution of the difficulty. But his own touchstone of decision was hardly better. This he found in the "same evidence" test. Proof of an unlawful purpose as to one woman, he reasoned, was not proof of an unlawful purpose as to the other. Therefore, the conclusion was that the accused rightly suffered two convictions and two sentences.

The Supreme Court reversed, rejecting, with Stewart, a semantic argument and rejecting also his generalized approach to the problem. Its answer was that Congress, in this particular statute, had been ambiguous in its mandate, and, therefore, following the usual principle of lenity in such situations, only one offense had been committed.0

Some months later, Stewart was faced with the case of one Rayborn who had been sentenced both for receiving stolen government property, and for receiving and possessing the same property in violation of the registration and tax requirements of the Internal Revenue Code. While not unimpressed with the force of the offender's argument that the IRC violation necessarily encompassed the simple receiving charge, Stewart thought, again relying on the "same evidence" test, that two offenses had been committed and that two punishments were proper. ${ }^{61}$

Rayborn had also been sentenced for the illegal transportation of arms and ammunition to one term because of the transportation of guns and bullets of one caliber, and to a second term for the transportation of guns and bullets of another caliber. However, again, only a single trip was involved. Although now mindful that "the answers that have been given under other criminal statutes are not necessarily helpful," Stewart regarded the Supreme Court's opinion in the earlier case as a clear sign that there was only one offense growing out of Rayborn's jaunt, however encumbered with the weapons of war he might have been..$^{52}$

Finally, Stewart had before him the case of one who had been convicted of the unlawful purchase of narcotics and also the unlawful sale, even though the only evidence of purchase was the possession involved in the sale. ${ }^{53}$ Relying on a 1932 Supreme Court case, ${ }^{54}$ which arose in a similar context, Stewart summarily affirmed the dual sentence. But

\footnotetext{
${ }^{50}$ Bell v. United States, 349 U.S. 81 (1955). The statute speaks of "Whoever knowingly transports in interstate . . commerce . . . any woman or girl for the purpose of prostitution." 18 U.S.C. $\$ 2421$ (1952). One has some sympathy with Mr. Justice Minton's inability to see the ambiguity here. 349 U.S. at 84 (dissenting opinion).

${ }^{51}$ Rayborn v. United States, 234 F.2d 368, 369-70 (6th Cir. 1956).

${ }^{52}$ Id. at 370-7I.

${ }^{53}$ Yancy v. United States, 252 F.2d 554 (6th Cir. 1958).

"s Blockburger v. United States, 284 U.S. 299 (1932).
} 
whereas in the Mann Act case less than four years before he had, when choice was relatively free, ${ }^{65}$ espoused the view there that two offenses had been committed, and that, therefore, there could validly be two sentences, he now indicated that the problem was not whether one of the elements of a transaction had been made the occasion of punishment, but whether cumulative punishment was proper when the various elements were combined. ${ }^{56}$ Informed by recent Supreme Court opinions, ${ }^{57}$ he concluded, tentatively, but with new insight: ${ }^{58}$

[I]t may be that the same evidence test, applicable to narcotics offenses under the rule of the Blockburger case, will someday be re-examined by the Supreme Court in the light of its decisions applying the "same transaction" test to other criminal statutes. [Citations omitted.] But that day has not yet come.

III

As a federal judge, Stewart has been no more able than his fellows to escape the complexities of the federal system and, particularly, the complexities of the role of the federal courts in that system. While his opinions in this field are not numerous, they are sufficient perhaps to indicate his pre-dispositions, especially when taken with an address that he delivered to the Ohio State Bar Association in May 1957. ${ }^{69}$ In this address, based in large part on Mr. Justice Frankfurter's opinion in the Lumbermen's Mutual case, ${ }^{60}$ Stewart joined in the suggestion that diversity jurisdiction be abolished. He put forward the familiar thesis that federal courts have some greater work to do than determining "whether a traffic light was red or green, or whether the truck was traveling at fifty miles an hour or only thirty-five." But his greatest emphasis was placed on the evils attributed to the diversity grant before

${ }^{\mathrm{BE}}$ One recalls Judge Frank's remark on the dilemma of a court of appeals judge: "[O]ur function, (as an inferior court) is often to serve as a judicial moon, reflecting as best we can, light from the sun of our system." To which he added: "The metaphor, of course, is inexact. Absent a clear light from our sun, we must frequently generate our own light." United States v. Gordon, 236 F.2d 916, 918 (2d Cir. 1956) (concurring opinion).

${ }^{60}$ Yancy v. United States, 252 F.2d 554, 556 (6th Cir. 1958).

${ }^{67}$ Prince v. United States, 352 U.S. 322 (1957); United States v. Universal C.I.T. Credit Corp., 344 U.S. 218 (1952).

${ }^{68}$ Yancy v. United States, 252 F.2d 554, 556 (6th Cir. 1958).

${ }^{80}$ Stewart, The Role of the Federal Courts in the Administration of Justice, $30 \mathrm{OH}$ BAR 475 (1957).

${ }^{60}$ Lumbermen's Mutual Casualty Co. v. Elbert, 348 U.S. 48 (1954) (concurring opinion). 
and after Erie. ${ }^{01}$ Before, there was, of course, the Black and White Taxicab case; ${ }^{62}$ before, there was forum shopping; before, rights varied "according to whether enforcement was sought in the state or in the federal court." Afterwards, the federal judges were "no longer free to make any independent contribution to the development or growth of the common law." Afterwards, the federal judges were to be "mere annotators of the decisions of the courts of the state."

In addition, Stewart gave some indication that he believes that the Erie doctrine is a matter of constitutional compulsion. His entire statement on the point, was: "And, by basing the conclusion which it reached in Erie v. Tompkins on Constitutional grounds, the Supreme Court placed its decision beyond the power of Congress to disturb."

As one might expect, Stewart was more guarded in his judicial utterances. For one thing, the problems which he faced on the court were of somewhat less magnitude than those he disposed of in an address to the Ohio lawyers of fewer than 3,000 words. Indeed, Stewart wrote no Erie problem opinion of any great significance. He was assiduous, it can be said, in his search for state law to the point of relying on the law reflected in a lower court dissent, when there was no majority opinion. ${ }^{63}$ And when referred to New York law, he accepted a New York federal district court's interpretation of an earlier state court opinion partly on the ground that the federal court really was another state court. ${ }^{64}$ Of slightly more moment, perhaps, are two cases where Stewart wrote no opinion. He concurred in deferring to a Kentucky district judge, "versed in Kentucky law," who, while there were no Kentucky decisions in point and authority elsewhere was sharply divided, had concluded that Kentucky would give no right of action against one who had left his keys in his car, and an accident involving a thief and a third party quickly followed. ${ }^{65}$ But he also concurred in holding that the right to dismiss without prejudice is governed exclusively by the federal rules. ${ }^{66}$

On federal jurisdiction questions, Stewart has carefully eschewed any

\footnotetext{
${ }^{a 1}$ Erie Railroad Co. v. Tompkins, 304 U.S. 64 (1938).

${ }^{n 2}$ Black \& White Taxicab Co. v. Brown and Yellow Taxicab Co., 276 U.S. 518 $(\mathrm{rg2s})$.

${ }^{13}$ Gettins v. United States Life Ins. Co., 221 F.2d 782 (6th Cir. 1955).

"John Hancock Mutual Life Ins. Co. v. Tarrence, 244 F.2d 86 (6th Cir. 1957). Stewart was also convinced that the district court had properly interpreted the New York decision.

${ }^{05}$ Frank v. Ralston, 248 F.2d 541 (6th Cir. 1957).

${ }^{80}$ Stern v. Inter-Mountain Telephone Co., 226 F.2d ${ }_{409}$ (6th Cir. 1955).
} 
expansionist tendency. Where one confined in a Michigan state hospital sought release not through habeas corpus, but through an action under the Civil Rights Act for a declaratory judgment and an injunction, Stewart affirmed the dismissal of the complaint. His basic idea was that federal courts were to be "chary of granting declaratory or equitable relief in an area of possible friction between state and federal jurisdictions." And the fact that the plaintiff chose to proceed under the Civil Rights Act, with its specific approval of a "suit in equity," made no difference. The policy of the statutory provisions relating to habeas corpus $^{68}$ was controlling, even if the language was not. And that policy clearly was that the "corrective processes" of the state, if at all adequate, must be exhausted in confinement cases before a federal court should grant equitable relief. ${ }^{\text {gr }}$

Likewise, Stewart declined to enjoin a prosecution under a city ordinance requiring "labor solicitors" to procure a license for soliciting at the cost of $\$ 25$. Each day's soliciting constituted, under the ordinance, a separate offense. The plaintiffs thus were faced with the possibility of multiple prosecutions if they chose not to comply. Moreover, they were asserting rights in a field which, it could be argued, had been preempted by federal legislation. Nevertheless, Stewart asserted that there was no threat of "irreparable injury which was so clear and immediate as to warrant the intervention of a federal court of equity."70 The plaintiffs were relegated to the choice of either refusing compliance with the ordinance and defending the criminal actions which were plainly threatened, or complying, since the license fee was only $\$ 25$ and there was readily available a state action for the recovery of the fee in which the validity of the ordinance could be tested.

Stewart has also made it clear that he views the "arises under" clause of the federal question grant ${ }^{71}$ quite narrowly. In Brotherhood of Railroad Trainmen v. New York Central R. Co., ${ }^{72}$ the railroad sought and obtained an injunction in the federal district court against a strike. Over Stewart's protest, a majority found that the plaintiff's claim to protection against a wrongful strike was one arising under "the laws of the United States," since, under those laws, the railroad had the duties of a common carrier, and, therefore, a correlative right to federal relief.

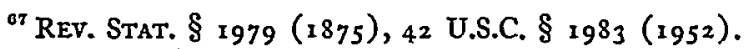

${ }^{68} 28$ U.S.C. $\$ 2254$ (1952).

${ }^{00}$ Williams v. Dalton, 231 F.2d 646 (6th Cir. 1956).

${ }^{\circ 0}$ Fuqua v. United Steelworkers, 253 F.2d 594, 598 (6th Cir. 1958).

$\because 28$ U.S.C. § 1331 (1952).
} 
Stewart's dissent adopts an earlier circuit court opinion by Judge Minton, where Minton took a quite opposite position on the nature of the right violated. ${ }^{73}$ The right to immunity from a wrongful strike was, in their (Stewart's and Minton's) view, a common law right given by a state. The railroad's involvement in interstate commerce and the duties imposed on it were only incidental to the railroad's claim and were too far in the background to be the basis of a federal claim.

\section{IV}

The appointment of Potter Stewart to the Supreme Court has given us notice that a new generation is taking over in law as well as elsewhere. Of his predecessors, only Mr. Justice Brennan finished law school so late as I93r. With Mr. Justice Stewart, the year is advanced to $\mathrm{r} 94 \mathrm{I}$ and the years of maturation advanced still further. He alone of the justices had his first serious encounter with the law after the revolution of 1937 and after the Supreme Court, in response to repeated importunities, began really to function as the guardian of civil rights. Furthermore, it is important to note that Stewart's world has been one in which the teachings of Pound and even Llewellyn and Frank have long since settled into the fabric of the legal order. These old victories he undoubtedly accepts, but only casually, much as one accepts the abolition of the forms of action. He thus does not have the passion of a Black or a Murphy in fashioning a new rampart. Neither does he have the feeling one senses in Harlan of puzzlement and wonder at a strange, new landscape. And, certainly, he does not smart under the disillusionment which gave overtones of tragedy to Jackson's career.

The point of all this perhaps is that Stewart will bring few new values within the compass of the law. But the point is also that he can be relied on not to depreciate those values he finds already there. He did not suffer the light from Yates to be extinguished, and in his keeping, the flicker from Menasche became incandescent. Happily, he inherits a more spacious legal world than did his predecessors. Perhaps his great task-and eventually his great achievement-will be to contribute toward making that legal world an orderly one.

\footnotetext{
${ }^{73}$ Toledo, P.\&W. R.R. v. Bhd. of Railroad Trainmen, $x_{32}$ F.2d 265, 272 (7th Cir. r942) (dissenting opinion).
} 